\title{
Intercultural Transfer and Balinese Gamelan Preservation
}

\author{
Emma Lo \\ Humboldt University Berlin, Germany \\ <emmayqlo@gmail.com>
}

\begin{abstract}
The influence and spread of traditional Balinese music over time and across regions has been conducted through a number of different channels. In addition to locally-focused efforts, cultural transfer has also contributed to the preservation of traditional Balinese arts. From the self-interested, strategic support of gamelan music by Japanese occupational forces to the global experimental music scene today, Balinese arts have been shared, supported, translated, and appropriated in various ways by a number of different actors to political, artistic, and commercial ends. Building on Michel Espagne's definition of cultural transfer and Stephen Greenblatt's concept of cultural mobility, this paper aims to outline different modes of cultural transfer (or "bridges," as Espagne would say), with explicit attention to power dynamics and multi-way flows of influence. Several key historical and contemporary examples of the transfer of traditional Balinese music will be discussed in an effort to better understand the relationship between cultural transfer and preservation.
\end{abstract}

Keywords: cultural transfer, tourism industry, music preservation, digitalization

\section{Introduction}

This paper examines several instances of the intercultural transfer of gamelan, and discusses potential impacts these instances have had on the preservation of the instrument and genre. Starting with the trajectory of Bali's tourism industry, followed by an overview of intercultural collaborations in contemporary music, the paper concludes with a probe into how new digital technologies make the sounds 
of gamelan more available and more malleable than ever in the global marketplace. With each instance, the author analyzes the conditions under which the transfer is taking place, using primary source interviews, secondary literature, and recordings to examine what might be lost or gained in transit.

\section{Theoretical Framework}

Cultural transfer emerged as a term in the 1980s through Michel Espagne and Michael Werner's scholarship on the transfer of literature and art between France and Germany in the 1900s, and has gradually developed into a field of study over the last several decades. Jin-Ah Kim (2015) made the case to broaden the field beyond its focus on printed media and culture, to connect the study of cultural transfer with the fields of music sociology and music anthropology. Although the terminology is still contested and therefore loose, the author employs the following definitions for the purposes of this paper. The working definition of 'culture' here leans on Stephen Greenblatt's concept of cultural mobility, which identifies dynamism as an intrinsic quality of culture, and moves away from strict, geopolitical delineations of culture by nation-state (Greenblatt et al 2009). Understanding culture as dynamic, however, can be at odds with the performance or marketing of said culture, as tourism "often depends on a commodification of rootedness" (Greenblatt et al 2009). The tension between self-identity and branded identity becomes an issue for Bali's cultural agents, and is discussed later in this paper. Michael Toggweiler and Manuela Rossini (2014) explain that "cultural transfer does not mean transfer between static and essentialized 'cultures' or the transfer of 'Culture' but, rather, a differing game and its very real yet unstable discursive effects (differences, identities) within the analytical framework of the "cultural".

In this contribution to the 'differing game,' the term 'transfer' is used to contextualize cultural mobility, and emphasize the factors that enable Balinese gamelan, or aspects of it, to move between cultures. Borrowing from Toggweiler and Rossini's framework (2014), the author will interpret instances of cultural transfer as sets of "conditions and dynamics of selection, translation, adaption or mutation within highly asymmetrical power relations." Musical exchange and collaboration do not happen in vacuums, but rather, are made possible by specific historical, political, and economic conditions. Those conducting intercultural transfer may try to decontextualize the transaction in the name of cultural relativism or universalism, but this merely obscures the living legacies of colonialism and late capitalism that enable such interactions. In differentiating contexts for several examples of the transfer of Balinese 
gamelan, this paper will examine the agents, funding structures, site, and time of transfer.

The spread of Balinese and Javanese gamelan over the past two centuries has been extensive, conducted through both intracultural and intercultural channels of transfer. At the core of gamelan's preservation and evolution are local efforts, which can be categorized into different types of intracultural transfer: through statefunded music academies and annual music festivals, intergenerational and interfamilial education, as well as the more recent incorporation of female performers into coed ensembles and formation of female ensembles (Harnish 2005). While these mechanisms of local transfer are vital to the preservation of gamelan, this paper will focus on recent instances of intercultural transfer, understood as transfer conducted between native and nonnative musicians, communities, and markets, and will enumerate some of the complex implications of these activities.

\section{Early Intercultural Encounters with Balinese Gamelan}

The most well-developed and highly visible site of intercultural transfer of gamelan is Bali's tourism industry. Michel Picard (1996) characterizes the birth of Bali's cultural tourism industry as a Dutch attempt at appeasement after their conquests of 1846-1908. By the end of the 1930s, Bali was attracting several thousands of tourists, mainly artists and anthropologists, who returned home to project orientalist images of "the last paradise" across Europe (Picard 1996). Although Japan's occupation of the Dutch East Indies from 1942-1945 saw a period of reduced tourism, Japanese occupational forces strategically promoted the preservation of Balinese arts in hopes of consolidating power through a political and cultural campaign for Asian solidarity (Cohen 2010). In 1967, General Suharto's "New Order" regime rapidly reopened Indonesia with the construction of hotels and a new international airport, leading to an explosion in numbers of visitors (Picard 1996). In response to this sudden influx, new legislation throughout the 1970s solidified Bali's commitment to cultural tourism and attempted to address its challenges. In trying to separate agama (religion) from adat (tradition), and constructing categories for types of dance (sacred, ceremonial, and secular), these policies aimed to protect certain aspects of Balinese culture from foreign influence and secularization, and commodify other parts for foreign consumption (Harnish 2005).

Bali's cultural tourism industry continues to expand and to influence Balinese identity construction (Ardhana 2017). Harnish (2005) elaborates on its impacts on Bali's musical identity over decades of transfer conducted through 
the tourism industry, arguing that "the tourist industry, foreign researchers, and global market have forever changed Balinese perceptions of themselves and their arts." Not only have non-local interferences affected local perceptions, they've also influenced the evolution of gamelan music. In this way, the cultural tourism industry has dual qualities, viewed as both the cause of 'cultural pollution' and an agent of 'cultural renaissance' (Harnish 2005). Fallout from colonial policies supposedly influenced the innovation of new styles of gamelan, according to Harnish:

"The twentieth century gong kebyar, the style that catapulted Bali into the international eye, developed as a result of colonisation. With most of their revenue terminated in the early colonial years, the court centres could not support their gamelans, and so pawned them to village organisations that transformed and decontextualised gamelan music for new aesthetic ends. The kebyar style first emerged by 1915 at competitions in north Bali, and, by the 1930 s, was dominating and defining Balinese music locally and internationally. Musicians and dancers, many of them commoners, pushed the music in new directions; the style required creativity and experimentation and the resulting virtuoso and richly ornamented playing influenced similar elements in the plastic arts. With its increased popularity, many clubs dismantled other gamelans to forge gong kebyar and the ensemble began to assume the repertoires and functions of these other gamelans."

In the wake of World War II, the pressures of the modern era had further ramifications for the performance gamelan, as Harnish (2015) describes:
"Modernisation has quickened the pace of life and altered values of the arts. The resulting compartmentalisation-along with tourism, telecommunications and arts entities-has triggered modifications in music and theatre forms. Music is often faster with greater ornamental parts (kotekan) and theatrical performances shorter. In many styles of theatre, the shorter length has reduced the number of compositions and the language preferences have shifted from archaic Javanese (Kawi) to common Balinese while humour is more emphasised than philosophical teachings."

The adjustments to ensemble, length of piece, and content seem to have been influenced by cultural exchanges between Balinese performers and tourist audiences, and these changes have endured.

\section{Contemporary Intercultural Collaboration and Hybridiza- tion}

Connections made through

Bali's cultural tourism networks have supported the emergence of intercultural collaboration on musical projects.

From the intercultural avant-garde and minimalist pieces of the 1970s$90 \mathrm{~s}$, to the rise of non-native gamelan ensembles in Europe, Japan, and the United States, there is ample evidence of cultural transfer through intercultural projects in the modern era, as Andrew Clay McGraw (2014) describes:

"During the second half of the twentieth century the conditions enabling Western artists to collaborate with local practitioners around the globe were underwritten by Western military and economic 
dominance. The reinvestment in cultural diplomacy following 9/11 re-energized the intercultural project, bringing together artists from America and its geopolitical allies in an effort to demonstrate the acceptance of American democratic principles through the arts. The precarious entanglements of contemporary Balinese culture and geo-politics are exemplified with the American gamelan movement and recent intercultural projects."

The influence of foreign investment is evident at the annual Bali Arts Festival, first held in 1979. The festival has become increasingly intercultural over time, featuring more and more foreign acts and musik kontemporer, a genre that combines gamelan with elements of contemporary classical composition. In an interview with McGraw (2014), composer and musician Dewa Ketut Alit reveals the festival's current agenda: "Festival committee members suggested that our intercultural performance would demonstrate to local audiences the extent to which the Balinese performing arts could go internasional." Sumarsam (2014) describes a similar trend at the Yogyakarta Gamelan Festival. In an effort to appeal to the younger generation, "hybridizing 'ethnic' with Western music is the main feature of the festival's music" (Sumarsam 2014).

Modern intercultural projects are not without evidence of the underlying national agendas. McGraw (2014) argues that "intercultural performance has for decades wound together rhetorics of civic universalism, humanism, and human rights, staging apparent demonstrations of the freedoms extended by the West while too often reproducing status quo relations of inequity." The inequity McGraw describes is visible in differences in visa permissions, compensation, and creative control. This persistent power imbalance in intercultural projects has both musical and cultural consequences: "The asymmetrical relationship that marks many of the contemporary intercultural projects with which the Balinese are engaged reminds us of Said's point that the orientalist works like a ventriloquist to make the Orient speak rather than its speaking freely" (McGraw 2014). This asymmetry may not be evident to Western audiences, but for the Balinese composers and musicians involved in intercultural projects, the results of Western direction can produce puzzlingly inauthentic results, as McGraw (2014) describes: "Non-native performers have used the tradition in ways that sometimes dumbfound native practitioners, including the occasional performance of anachronistic repertoire and the association of gamelan with meditation, music therapy, elementary education, and prison programs."

\section{Extraction and Digitalization}

While intercultural collaborations still solicit active input, if not direction, from local artists, what happens when the instrument is completely extracted 
from its native environment and cultural context? Digital tools developed over the last two decades separate, for the first time, the recorded sounds of gamelan from its performers and repertoire. In 2008, Soniccouture, a virtual instrument production company, run by Dan Powell and James Thompson, released a sample library assembled from 8,000 recordings of The London Symphony Orchestra's Semara Dana Gamelan Ensemble and Gamelan Batel Ramayana in Toronto. These recordings have been transformed into a plug-in for music production software, in which composers and producers can separate and recombine 30 different instruments from both ensembles, as well as retune to any scale, be it pelog, slendro, or the Western heptatonic scale. The product, marketed under an 'Ethnic' category on Soniccouture's website, is "ideal for anyone who wants the essence of gamelan-the magical flavorwithout breaking the bank or the hard drive," despite being one of their most expensive products at 199 Euro $^{*}$. The 48-page instruction manual contains a brief history of gamelan, a breakdown of traditional scales and modes, and an introduction to each instrument. The product's literature and product reviews are punctuated by words such as 'magical,' 'ethnic,' 'exotic,' and 'ancient' - the same orientalist and essentialist vocabulary used at the

* Soniccouture Website. "Products page." http:// www.soniccouture.com/en/products/ Accessed April 6, 2020 beginning of the 20th century to market Bali as a tourist destination (Picard 1990).

While this project preserves high levels of articulation and nuance captured by its extensive recordings of each instrument, it also disrupts essential elements of gamelan. By allowing the consumer to isolate individual instruments and notes, the 'thick' texture of gamelan vanishes. In addition to deviations in sound, there is an obvious loss in the elimination of interpersonal transmittal. The gamelan tradition of teaching and learning by rote rather than by notation necessitates a teacher-student relationship to conduct the transfer of knowledge, whereas the digital package provides the consumer with the instant ability to 'play.' The London Symphony Orchestra itself offers a free, although limited, online composition game, which also offers short descriptions of instruments and suggestions for how to arrange a short musical phrase. In some ways, these digital developments are similar to other forms of intercultural transfer in the way they both preserve and also detract from musical traditions, harkening back to the cultural pollution vs. cultural renaissance duality. But the new technology seems to go far beyond early field recordings, which detached gamelan music from live performance, but preserved the sound of the cohesive ensemble and documented traditional compositions. Soniccouture's sampling 
library functions differently in that it increases the range of mobility of gamelan, but severs the instrument's sounds from the instrument itself, and puts great distance between the product and the culture from which it originates.

\section{Conclusion}

The long history of intercultural transfer involving the Balinese gamelan has seen many developments in the ways in which transfer occurs. Distribution of recordings, local performances for tourist audiences, non-native gamelan ensembles, Western compositions inspired by Balinese music, and intercultural collaborations are just a few examples of the ways gamelan has been transferred across cultures and over time. These different kinds of cultural transfer have had a range of consequences on gamelan music and the way is it performed. Recent digital developments reopen lines of inquiry about how the integrity of gamelan music is impacted by cultural transfer, how far preservation stretches alongside the evolution of the genre, and the gatekeepers of gamelan today.[]

\section{Bibliography}

Ardhana, I K. "Understanding the Balinese Multicultural Society in a Globalized World." 2017. Accessed April 6, 2020. https://simdos.unud.ac.id/uploads/file_penelitian_1_dir/ c9bbbefaa9548e5f97538df4f5d219a4.pdf

Cohen, Matthew Isaac. Performing Otherness: Java and Bali on International Stages, 19051952. Basingstoke: Palgrave Macmillan, 2010

DeVale, Sue Carole, and I Wayan Dibia. "Sekar Anyar: An Exploration of Meaning in Balinese "gamelan"." The World of Music 33, no. 1 (1991): 5-51. Accessed April 6, 2020. www. jstor.org/stable/43562776.

Michel Espagne, and Michael Werner. "Deutsch-französischer Kulturtransfer im 18. und 19. Jahrhundert. Zu einem neuen interdisziplinären Forschungsprogramm des C.N.R.S. " In Francia 13 (1985).

Greenblatt, Stephen, Ines Županov, Reinhard Meyer-Kalkus, Heike Paul, Pál Nyíri, and Frederike Pannewick. "Cultural Mobility: an Introduction." Chapter. In Cultural Mobility: A Manifesto, 1-23. Cambridge: Cambridge University Press, 2009. doi:10.1017/ CBO9780511804663.001.

Harnish, David. "Teletubbies in Paradise: Tourism, Indonesianisation and Modernisation in Balinese Music.” Yearbook for Traditional Music 37 (2005): 103-23. Accessed April 6, 2020. www.jstor.org/stable/20464932.

Kim, Jin-Ah. "Cultural Transfer as a Branch of Research for Music Sociology and Music Anthropology." International Review of the Aesthetics and Sociology of Music 46, no. 1 (2015): 43-53. Accessed April 6, 2020. www.jstor.org/stable/24327326.

McGraw, Andrew Clay. Radical Traditions: Reimagining Culture in Balinese Contemporary Music. New York: Oxford University Press, 2013. Oxford Scholarship Online, 2014. doi: 
10.1093/acprof:oso/9780199941407.001.0001.

Picard, Michel. "'Cultural Tourism" in Bali: Cultural Performances as Tourist Attraction." Indonesia, no. 49 (1990): 37-74. Accessed April 6, 2020. doi:10.2307/3351053.

Rossini, Manuela. "Cultural Transfer: An Introduction (with Michael Toggweiler)." Word and Text: A Journal of Literary Studies and Linguistics. 2. (2014): 5-9. Accessed April 6, 2020. https://www.academia.edu/9776594/Cultural_Transfer_An_Introduction_2014_

Soniccouture Website. "Products page." http://www.soniccouture.com/en/products/. Accessed April 6, 2020.

Sumarsam. "PAST AND PRESENT ISSUES OF JAVANESE-EUROPEAN MUSICAL HYBRIDITY: GENDHING MARES AND OTHER HYBRID GENRES.”In Recollecting Resonances: Indonesian-Dutch Musical Encounters, edited by Barendregt Bart and Bogaerts Els, 87-108. LEIDEN; BOSTON: Brill, 2014. Accessed April 6, 2020. www. jstor.org/stable/10.1163/j.ctt1w76trp.7. 